\title{
Local Self-Governments in Dealing with Mass Migrations and Integration of Migrants in Hungary
}

\author{
István Temesi* \\ https://doi.org/10.31297/hkju.19.3.5 \\ UDK 341.43:352(439) \\ 351.756(439) \\ Preliminary scientific report / prethodno znanstveno priopćenje \\ Received / primljeno: 5.1.2019. \\ Accepted / prihvaćeno: 28.4.2019.
}

In 2015, masses of migrants crossed the Hungarian border. The reaction of the government was quick and radical. It closed the borders and denied almost all migrants the possibility to enter. Despite the fact that most of the migrants had just passed through the country without the intention to stay, the government took strict control of the issue of migration. Today all matters related to migrants and asylum seekers belong to the central government and its agencies. Local self-governments only have a small and restricted space to act in concerning migration. Notwithstanding the strong administrative centralization, another question is: what is the local self-governments' policy like concerning migration?

István Temesi, Associate Professor, National University of Public Service, Budapest, Hungary (izvanredni profesor Nacionalnog sveučilišta za javnu upravu, Budimpešta, Mađarska, e-mail: temesi.istvan@uni-nke.hu)

ORICD ID: https://orcid.org/0000-0002-6686-3007 
Keywords: immigration authority, integration of migrants, local policy, local self-government, mass migration, refugees

\section{Introduction}

One might think that due to the delegation of public duties to lower levels of public administration, local self-governments are charged by many public tasks including those related to migration and migrants, especially when migration is a determinant phenomenon around the World. The aim of this paper is to introduce the role of local self-governments in dealing with migration in Hungary. This is a difficult challenge to meet because relevant literature on the issue, meaning appropriate scholarly and professional sources, is not rich. That is why the main sources for this paper are relevant Hungarian legal rules including acts of the Parliament and decrees of the government and of the local councils. The empirical method of the research is solid because data collection is mainly based on public official reports of different authorities and documentation of the facts. This paper was prepared following the same method applied by the author for the elaboration of his article published in a previous issue of this journal (Temesi, 2018).

The first part of this paper introduces the background of local self-governments' role in the integration of migrants, including a short presentation of the local government system and the central government's policy. National policy formulated by the government appears in legal rules while the role of Hungarian local self-governments in the integration of migrants was examined instead on the basis of several cases in which important local decisions were made by the municipality.

\section{System of Local Self-Governments in Hungary}

In order to understand the role of local self-governments in dealing with migration a short introduction of the local self-governments' system is necessary. The democratic and decentralised system of local self-governments was established by a revision of the Constitution and the adoption of the Local Government Act in 1990. This system was revised and modified following a turning back for recentralisation in 2011. Consequently, some 
functions and tasks of the municipalities were delegated to the local authorities of the central government meaning its deconcentrated bodies; especially the county state representatives and their district offices. The control over legality exercised by the central government became stricter, while the main pillars of the structure were not changed (Temesi, 2017, pp. 420-423).

In Hungary, local self-government exists on two levels: the commune ${ }^{1}$ and the county. The relation between the units of these two levels is not a hierarchical one. ${ }^{2}$ The scope of authority of the local self-governments of the communes includes villages (sometimes translated as communes), cities (sometimes translated as towns), county district seats and districts of the capital city. The county is a territorial self-government, while the capital city has both the status of a commune and a territorial self-government at the same time. In Hungary, there are 3177 municipal self-governments including villages, cities, the capital city and its districts, and there are 19 counties. The average number of inhabitants per municipality is 3100 . Consequently, the average Hungarian local self-government is small and has a rather weak capacity concerning service provision.

Communes are empowered by the Local Government Act $^{3}$ to perform the duties and to exercise the powers required by legislation as well as those taken on voluntarily. The competences of local self-governments are thus of two types: delegated tasks, which serve national interests; and local government tasks, which serve local interests. The latter are local public affairs. The central government assumes responsibility for delegated tasks, but their economic implementation is only possible on the local level by organs of the local self-government, particularly, by the clerk (sometimes translated as "chief executive"). While he/she is appointed by the elected mayor, the clerk is subordinate to the territorial state representative. Delegated tasks are passed on to communes by legislative acts of the Parliament or by government decrees issued with the Parliament's authorization.

Local government tasks can only be local public affairs. The sphere of local public affairs is given by the Local Government Act in the form of an exemplificative list, meaning that further elements can be added by Acts of Parliament as duties, or may be undertaken by a given commune. Local

${ }^{1}$ Also called settlements in the official translation of legal texts.

2 The units of the two levels of local self-government are equal, which means that any superiority or subordination is not allowed between them, however, tasks and obligations required by law can be different depending on the units' size, population or other features specified by law.

${ }^{3}$ Legislative Act No. CLXXXIX of 2011 
government tasks are of two types: obligatory tasks and volunteer tasks. Any obligatory task can be defined as a duty by a legislative act of the Parliament. Its fulfilment is an obligation, but it is financed by the central budget. Legislative acts should differentiate the communes by size, population or capacity when assigning duties to local self-governments.

Volunteer tasks can be any local public affair that any local self-government may volunteer to manage, unless it is reserved for the exclusive competence of another body by a rule of law. Local self-governments may do anything within the law to further voluntarily accepted common local affairs. However, volunteer tasks should not threaten the performance of obligatory tasks and the exercise of powers prescribed by law, and they may be financed from proprietary revenues or separate funds allocated for that purpose.

In 2012, when the Fundamental $\mathrm{Law}^{4}$ and the new Local Government Act of 2011 entered into force, the competences of the communes were not considerably changed regarding local government tasks. Local government competences were reduced later, in 2013, when county districts were set up as local deconcentrated units of the central government. Many delegated tasks falling within the scope of responsibility of the local clerk were taken over by the office of the county district. One of these delegated tasks taken over by the county district in 2013 was the management of services for refugees. As a result, Hungarian local self-governments do not have any obligatory tasks related specifically to the service provision of persons recognised as refugees. A further consequence is that all the provisions and benefits are provided by the central government, which means the main actor in this respect is the Immigration and Asylum Office.

The main task of local self-governments therefore is to give information and ensure its flow concerning persons who are granted any kind of protection, but this does not mean that service provision aimed at social integration of migrants would not be possible in the form of volunteer tasks of a municipality.

\section{Migrants and Refugees in Hungary in Numbers}

It is interesting to examine the number of asylum seekers and recognised refugees in recent years. It is not a surprise that the number of asylum seekers arriving in Hungary decreased in 2016 (only 29,432) when com-

\footnotetext{
${ }^{4}$ This is the official name of the Constitution.
} 
pared to their number in $2015(177,135)$, due to the border fence that was built in the autumn of 2015. Their number in 2017 is even less, only $3,397.5$

The table below shows the number of recognitions according to their status, as well as refused claims and dissolved procedures for the period 2015-2017.

Table 1. Number of decisions made by the Hungarian Immigration and Asylum Office on request for asylum in recent years

\begin{tabular}{|c|l|r|r|r|}
\hline & Recognised as & 2015 & 2016 & 2017 \\
\hline 1 & $\ldots$ Refugee & 145 & 154 & 106 \\
\hline 2 & $\ldots$ Beneficiary of subsidiary protection & 356 & 271 & 1100 \\
\hline 3 & $\ldots$ Beneficiary of temporary protection & 6 & 7 & 75 \\
\hline $\begin{array}{l}\text { Sum of } \\
1+2+3\end{array}$ & $\begin{array}{l}\text { Positive decisions on asylum applica- } \\
\text { tions (Sum) }\end{array}$ & 507 & 432 & 1291 \\
\hline & Refused & 152260 & 49479 & 2880 \\
\hline & Procedure dissolved & 2917 & 4675 & 2049 \\
\hline
\end{tabular}

Source: Table 1 has been prepared by the author using official data provided by the Hungarian Immigration and Asylum Office. The data was retrieved from the official site of the Hungarian Immigration and Asylum Office: http://www.bmbah.hu/index.php?option=com $\mathrm{k} 2 \&$ view $=$ item\&layout $=$ item\&id $=492 \&$ Itemid $=1259 \&$ lang $=$ en $\#$

The number of recognized refugees can be qualified constant, but the number of positive decisions on all types of asylum applications has increased if all three categories are considered. The fact that there have been 1291 positive decisions in 2017 does not mean anything unless we consider the political aims and the measures taken by the government in Hungary. It is interesting that the number of accepted applications has been increasing: 1291 accepted requests in 2017 with respect to only 507 in 2015, at the height of mass migration. Despite strict measures being taken by the government in order to stop immigration since 2015, the number of accepted requests is higher and higher. Although the government declared to stop immigration in 2015, and has taken appropriate

5 The data was retrieved from the official site of the Hungarian Immigration and Asylum Office:http://www.bmbah.hu/index.php?option=com_k2\&view=item\&layout=item\&id $=492 \&$ Itemid $=1259 \&$ lang $=$ en $\#$ 
measures since then, the number of legally arrived immigrants was higher in 2017 than two years earlier.

Additional insight might be gathered if the total number of positive decisions on asylum applications is compared with other EU countries. ${ }^{6}$ In 12 other EU countries, the number of positive decisions on asylum applications is less than in Hungary. ${ }^{7}$ Furthermore, if the number of accepted applications is compared on the basis of a population of one million, then Hungary has accepted 130 applications per one million inhabitants. This number is bigger than it is in 10 other EU countries. ${ }^{8}$ It is interesting that Hungary, being the only country which officially follows a very strong anti-immigration policy and has taken considerable measures against migration, received relatively more immigrants than other countries where the government's policy does not focus on the migrant issue. The main elements of this anti-migration policy are presented in the following chapter.

\section{Government Policy on Migration in Hungary}

The reaction of the Hungarian government to mass migration has been to declare resistance in every possible way, aiming to stop it. As is well known, the government decided to build a border barrier along the state border impacted by mass migration. As a first step, a 175 kilometre (109 mile) long and 4 metre (13 foot) high border barrier was built, sealing the border between Hungary and Serbia in September 2015. As a second step, the same type of barrier along the 348 kilometre (216 mile) border with Croatia was completed as a second item in October of the same year. The border barrier, or as it is officially called "the temporary fence for the purpose of border protection” closed off the border in the countryside between official border checkpoints. In the context of migration policy, legal instruments are as important as physical ones. The central element of legal instruments is the „crisis caused by mass migration" that may be declared by the government in

${ }^{6}$ Source: Eurostat/news release, 67/2018 (19 April 2018) https://ec.europa.eu/eurostat/documents/2995521/8754388/3-20032018-AP-EN.pdf/50c2b5a5-3e6a-4732-82d0$1 \mathrm{caf} 244549 \mathrm{e} 3$

${ }^{7}$ Czech Republic 145, Estonia 95, Ireland 720, Croatia 170, Latvia 275, Lithuania 295, Luxembourg 1130, Malta 815, Poland 560, Portugal 500, Slovenia 150, Slovakia 60.

${ }^{8}$ Czech Republic 15, Estonia 70, Spain 100, Croatia 40, Lithuania 105, Poland 15, Portugal 50, Romania 70, Slovenia 75, Slovakia 10. 
the form of a decree, based on the authorisation of a legislative act. In September 2015, the modification of Legislative Act No. LXXX of 2007 on Asylum made the declaration of crisis caused by mass migration possible for a period of 6 months. Since September 2015, this crisis has been permanent because the government was entitled to extend its duration for another 6 months, which consequently happened 6 more times. Ultimately, the crisis was extended again in September 2018 and will last up to 7 March 2019. ${ }^{9}$

The modification of the Legislative Act on Asylum was only one of the elements of the legislative package of September 2015. Other significant legislative acts were modified at the same time, such as the Penal Code, the Criminal Procedure, and the Act on the Administrative Procedure. A further reaction of the government in the legal dimension was another legislative package adopted in June 2018. The legislative package is called "Stop Soros," after the name of the Hungarian born American businessman George Soros. The content of this package was published early on in 2018, but it was adopted in the form of legislative acts only in June after the general elections, which means that it became part of the political program of the government in the campaign.

As a base of the package, the Fundamental Law of Hungary was modified first. One of these important modifications of the Constitution was a declaration stating that the settling of foreign population in Hungary was not allowed, and that citizens of foreign countries would be allowed to live in Hungary only if an individual claim of such a person was approved by the Hungarian authorities (except for citizens of the EU). ${ }^{10}$ One of the further modifications resulted in a declaration that authorized the police to participate in hindering illegal immigration. ${ }^{11}$

In addition, this package has several further elements mainly in the form of the modification of legislative acts, such as Legislative Act No. VI of 2018 on the Modification of Certain Legislative Acts Related to Measures Against Illegal Immigration. This act modified 9 further legislative acts including the Legislative Act on Asylum, the Legislative Act on Contraventions, the Legislative Act on the Police, and as one of the most

${ }^{9}$ Government Decree No. 159 of 3 September 2018 that modified Government Decree No. 41 of 9 March 2016. The latter decree extended the crisis for the second time in March 2016.

${ }^{10}$ Article XIV, Section 1 of the Fundamental Law of Hungary

${ }^{11}$ Article 46, Section 1 of the Fundamental Law of Hungary 
important, the Penal Code. In the Penal Code, a new criminal offence appeared: facilitation, support of illegal migration. ${ }^{12}$ Legislative Act No. XLI of 2018 was the next important element of the package..$^{13}$ From August 2018 it introduced a new tax called "immigration super-tax" that should be paid by all those supporting immigration into Hungary or by all supporting organisations that facilitate immigration into Hungary. ${ }^{14}$ In this case it is important to note that the super-tax is to be paid regardless of whether illegal immigration is supported.

\section{Local Self-Governments and Integration of Migrants}

One would think that from a certain point of view there is no difference between a recognized refugee and a Hungarian citizen because Legislative Act No. LXXX of 2007 on Asylum declares that, with some exceptions, a refugee shall have the rights and obligations of a Hungarian citizen. ${ }^{15}$ The question is the extent of these exceptions. The Act on Asylum enumerates some of these exceptions and further exceptions may be determined by the Parliament in its legislative act and by the government in its decree.

It is important to note that the Legislative Act on Asylum does not exclude refugees either from participating in municipal elections or a local referendum. This is important because refugees may participate in the election of the mayor as well as members of the local council. However, this right can be exercised only by a person recognized as a refugee, not by all migrants. The right to elect may be important for the integration of refugees, although it is guaranteed by the legislative act and is not a service provided by a local self-government.

The integration of migrants is much more a key question in the case of persons seeking asylum than it is for refugees, because a refugee is entitled to almost all the rights as a Hungarian citizen including public services, which makes his integration less difficult. When it comes to the

12 Legislative Act No. C of 2012 on the Penal Code. Art. 353/A.

${ }^{13}$ Legislative Act No. XLI of 2018 on the Modification of Certain Legislative Acts on Taxation and Related Legislative Acts as well as on the Immigration Super-tax.

14 „All” means every natural (person) and legal entity including organizations.

${ }^{15}$ Article 10, Section 1 of the Legislative Act No. LXXX of 2007 on Asylum 
issue of the integration of migrants, it is more important to examine the situation of those who are waiting for recognition of their refugee status. This means that all types of migrants, other than those who received the refugee status, should be examined.

Local self-governments are not obliged to perform many duties concerning the integration of migrants. They only have a few tasks among their delegated tasks or their obligatory tasks. However, they have different kinds of obligations related to migration and they may undertake volunteer tasks related to migration. The obligations of local self-governments imposed by the Legislative Act on Asylum cannot be said to serve the integration of migrants. As a possible obligation of local self-governments, the Legislative Act on Asylum authorizes certain authorities concerned in the management of migration to use the goods, property and distrainable property, belonging to a local self-government or to a company owned by a local self-government in a time of a crisis caused by mass migration. This temporary transfer of the local-government's belongings to the state may last for 6 months and compensation is to be paid by the state. ${ }^{16}$ In such cases, local self-governments are obliged to keep a record of the persons recognized as refugees, beneficiaries of subsidiary protection and beneficiaries of temporary protection if such persons are subsidized. These records contain data related to the tasks of the local self-government. ${ }^{17}$

Basic living conditions for migrants, including subsidies (Temesi, 2018, pp. 439-443), belong to the state and are mainly provided by the state, meaning the Hungarian Immigration and Asylum Office. There are of course some exceptions and the communes also have duties to perform. Government Decree No. 301 of 9 November 2007 on the execution of the Legislative Act on Asylum makes it possible for the authority, meaning the Hungarian Immigration and Asylum Office, to make a contract with a local self-government, or with NGOs and economic actors as well, for the provision of such subsidies; including welfare services or education of the Hungarian language. ${ }^{18}$ Consequently a local government may undertake responsibilities by contract that is not imposed by law. A real obligation is that mayors of local self-governments are obliged to organise a funeral if a person claiming asylum dies. ${ }^{19}$ The costs are however reimbursed by the

\footnotetext{
${ }^{16}$ Article 80/B. of the Legislative Act No. LXXX of 2007 on Asylum

${ }^{17}$ Article 85. of the Legislative Act No. LXXX of 2007 on Asylum

18 Article 14 of the Government Decree No. 301 of 9 November 2007

${ }^{19}$ Article 25 of the Government Decree No. 301 of 9 November 2007
} 
state. This task is not typically one that serves the integration of migrants. Only primary health care services require any real activity from the communes because they should be provided for the migrants by the commune although they are financed by the state.

It is to be stated that local self-governments do not have obligatory tasks especially designed for the integration of migrants. Consequently, almost all that a Hungarian local self-government does for the integration of migrants is decided by the local council or by the mayor and is part of its local policy. After reading the legal texts, one cannot easily understand what a commune in Hungary is to perform concerning the integration of migrants. As mentioned before, local self-governments manage public services in the framework of local public affairs for asylum seekers if they have already been recognized and allowed to stay legally in Hungary. What local self-governments have done, or did for migrants in a time of mass migration should be distinguished. The number of migrants was presented and it is clear that there have not been masses of migrants arriving with the intention of staying in Hungary in recent years. Their integration and assisting them is mainly the responsibility of the state. For a better understanding of the local self-governments' role in the migration issue, it is better to examine their attitude and their political decisions through different cases.

\subsection{Budapest, 2015}

In 2015, Budapest made considerable efforts for the assistance of migrants before the closure of the state border, when thousands of migrants passed through the capital city. ${ }^{20}$ Most of the migrants arriving illegally across the border headed for Budapest and intended to continue their travel by train from what is considered the centre of the railway system. Consequently, masses of migrants concentrated around the three main railway stations of Budapest. The capital city could not ignore the situation, which is why it took some measures, mainly in the form of humanitarian aid. In August 2015, three so called transit zones were established where water supply including drinking water, restrooms and shower-rooms including disinfection, were made available 24 hours a day for migrants. The local self-government owned public transport company operated direct bus lines between the three zones and managed public sanitary facilities throughout

20 The officially estimated number of migrants in Hungary was 110,000 on 10 August 2015. 
the area. Medical attendance was not provided by the city because hospitals are maintained and managed by the central government. However, medical attendance was assured by the Hungarian Charity Service of the Order of Malta, while food and clothing were provided by volunteers. Security was ensured by the police that belonged to the central government. Entering the transit zone was not compulsory, but anyone could benefit from their services if they wished to. ${ }^{21}$

Concerning the measures taken by the local self-government of Budapest, it is important to underline that the mayor of Budapest declared that $\mathrm{Bu}-$ dapest provided temporary care for migrants and did not intend to accommodate them..$^{22}$ Another important element to mention is that the transit zones were operated temporarily. They were closed in September 2015 due to the lack of interest deriving from the reduction in the number of migrants passing through Budapest. Today, masses of migrants cannot be seen in the streets of Budapest and a search for services for migrants provided by the capital city on its Internet home-page ${ }^{23}$ does not give any results. An information centre for migrants that was established by the municipality and located in the building of the city hall was closed in 2018.

\section{2. Ásotthalom, 2016-2017}

On 23 November 2016, a modification of local Decree No. 12 of 30 April 2014 on Basic Rules of Social Coexistence entered into force in the village of Ásotthalom. ${ }^{24}$ This modification was adopted by the local council and as a consequence the decree forbade wearing burka, niqab and chador, or other such clothes that cover the whole body and head including the whole face or part of it, as well as burkini. It also forbade many activities typically performed by Muslims, such as the acts of a muezzin, in the village. ${ }^{25}$ The decree clearly expressed the intention of the municipality that they did not want asylum seekers to stay in the village. In 2017 after a procedure

21 On 8 August 2015, on the opening day of the first transit zone, 600 migrants used it - https://hvg.hu/itthon/20150811_Szerdan_nyilik_a_Deli_aluljarojaban_az_uj http://www. kozterulet-felugyelet.hu/hirek/megnyilt-az-elso-tranzitzona

22 http://budapest.hu/Lapok/Tarl\%C3\%B3s-a-f\%C5\%91v\%C3\%A1 ros-csak\%C3\%A1tmeneti-ell\%C3\%A1t\%C3\%A1st-ny\%C3\%BAjt-a-migr\%C3\%A1nsoknak.aspx

23 http://budapest.hu/Lapok/default.aspx

24 Population 3,856 (in 2017).

25 Section 1 of Decree No. 25 of 23 November 2016 of the Commune of Ásotthalom. 
launched by the ombudsman, these new dispositions of the decree were annulled by the Constitutional Court due to their incompatibility with the Constitution. The local council did not give up however and tried to modify the same decree with the same objective, but using different expressions and trying to avoid the use of words that directly concern Islam. ${ }^{26}$ On this occasion, the Curia, the highest forum of jurisdiction, annulled the new dispositions that entered into force on 25 November 2017, due to their incompatibility with different Acts of Parliament as higher rules.

\subsection{Esztergályhorváti, 2017}

On 4 September 2017, the council of a small village ${ }^{27}$ of West-Hungary called Esztergályhorváti, adopted a local decree that modified the decree on the basic rules of social coexistence. ${ }^{28}$ The new decree obliged all hotel-keepers to control the necessary documents on vaccination of all their guests and report them to the local government. The decree also stated that accommodation in the village was available only for those persons able to present such documents on the spot. It is important that the force of the decree covers all categories of migrants. Foreign or Hungarian tourists were not obliged to do so. Consequently, the restrictions concerned only and exclusively migrants.

The antecedents and explanation of this decree is that a home owner declared that she would allow persons seeking asylum and recognized as refugees, mainly children, to spend a couple of weeks in her residence, which was used as a vacation house in the village. ${ }^{29}$ Since many of the local people did not like the idea that refugees would be arriving into their village and had no legal means by which to inhibit anyone from lending a house to somebody, they found a solution with the assistance of the local government. The local council quickly passed the above mentioned decree, thus causing a risk of liability to the house owners in the village. This case demonstrates that the attitude of the local council is strongly influenced

${ }^{26}$ Decree No. 18 of 23 November 2017 of the Commune of Ásotthalom.

${ }^{27}$ Population 429 (in 2017)

${ }^{28}$ Decree No. 9 of 5 September 2017 of the Commune of Esztergályhorváti on the Modification of the Decree No. 8 of 4 July 2016 on the Basic Rules of Social Coexistence http://www.njt.hu/njtonkorm.php?njtcp=eh6eg3ed0dr7eo0dt3ee2em3cj8by7ca8ce3ce4ca7bx2

29 This owner is an Austrian citizen who lives in Austria and has a house in this Hungarian village. 
by local voters and there is no doubt about the migrants' slim chances to integrate, as even the first steps of their integration were impossible.

\section{4. Öcsény, 2017}

As a result of the case of Esztergályhorváti, the case of Öcsény is even more strange. A pension owner living in the village of Öcsény became aware of the attitude of the people in the previously mentioned village and invited the same group of youths to stay in his pension for a vacation. In the village of Öcsény ${ }^{30}$ however, the local self-government did not have time to react in the form of any decision, because the residents suddenly decided to act themselves. A public hearing on the issue was held where different opinions were presented, but the decision was not made in a legal form. This means that the municipality did not inhibit anybody from doing anything or prohibit anything. Nonetheless, by the next day, the debate had been decided because somebody let the air out of all the tires of the owner's car and did the same with the tires of his son's car. The pension keeper dropped his plan. The mayor of the commune did not agree with this action, however he did not demonstrate his solidarity either. $\mathrm{He}$ tendered to resign but ultimately remained in office. ${ }^{31}$ As a result, nobody was invited into the village for a vacation.

\subsection{Climate and Local Self-Governments' attitude to Migrants}

One would think that the local self-governments' attitude to asylum seekers is not entirely clear because only a few cases are known and show up as the subject of legal concern. The example of Budapest leads us to think that local self-governments tried to react quickly to solve the problems that appeared due to mass migration in 2015. It is true that many local self-governments affected by mass migration tried to provide provisional services for migrants passing through their communes in 2015 even though at that moment the reaction of some of the other municipalities

\footnotetext{
30 Population 2380

31 https://index.hu/belfold/2017/09/27/lemondott_az_ocsenyi_polgarmester_miutan botrany_lett_a_faluban_udulo_menekultekbol/https://index.hu/belfold/2017/09/26/kocsigumikat_szurkaltak_ki_a_falusiak_annyira_nem_akarjak_a_menekulteket/
} 
was rather different, as their deliberative bodies declared that they would not agree with the establishment of a reception centre, reception station or community accommodations in their city or village. It is important to outline that all the establishments, including the reception centres for asylum seekers, have been established and are managed by the central government, meaning that a given local self-government has not been charged with this task.

The question was removed from the agenda when the central government decided to close the borders and asylum seekers did not arrive in such a great number as before. Consequently, some of the reception centres were even closed-down. In 2015 the central government decided to closedown the reception centres in Debrecen. ${ }^{32}$ In 2016, a further centre was closed-down in Szentgotthárd, while the temporary sites' operation was suspended in Körmend, Nagyfa and Bicske. This suspension lasts until today. In Hungary three reception centres and community accommodations have sites ${ }^{33}$ and two "closed" reception centres are operating today. ${ }^{34}$ None of them are managed by local governments.

As we can see, the situation has changed since August 2015 and local-governments are otherwise not obliged by law to support the integration of migrants. That is why their attitude to migrants cannot be understood on the basis of their services, but instead it can be evaluated on the basis of their decisions. In late 2017 the deliberative body of certain local self-governments began to declare their policy on migration in the form of a resolution passed by the council. The adoption of resolutions continued in early 2018. The source of these political declarations was the central government's policy on migration.

In April 2018 general elections were held in Hungary. There is no doubt that migration has been one of the main political issues in internal politics since 2014 and as such it proved to be a useful instrument of political mobilisation in the election campaign, mainly on the side of the governing parties. A resolution by the Parliament was taken just before the election campaign as an element of the political strategy of the government. The Hungarian Parliament adopted its Resolution No. 29/2017 of 13 December 2017 on the European Parliament's Resolution on the Implementation of the So-

\footnotetext{
${ }^{32}$ Resolution of the Government No. 1724/2015 of 7 October 2015

33 Vámosszabadi, Balassagyarmat and Kiskunhalas

${ }^{34}$ Békéscsaba, Nyírbátor. These, so called "closed reception centres" do not allow refugees and asylum seekers to move freely in and out of the centre.
} 
ros-Plan. In Hungary, the „implementation of the Soros-Plan” refers to the Draft European Parliament Legislative Resolution on the proposal for a regulation of the European Parliament and of the Council establishing the criteria and mechanisms for determining the Member State responsible for examining an application for international protection lodged in one of the Member States by a third-country national or a stateless person (recast). ${ }^{35}$ This resolution of the European Parliament was interpreted specifically by the resolution of the Hungarian Parliament as the Soros-Plan. One of the main ideas or objectives of the resolution of the Hungarian Parliament is that Hungary does not accept or refuse permanent settlement and obligatory distribution of asylum seekers to the detriment of the European nations. Also, this resolution declared that the permanent import of immigrants and their distribution based on compulsory quotas would irreversibly alter the future and culture of Europe (Nagy, 2018, p. 29). The adoption of this resolution, as well as its proposal before the adoption, influenced most of the local self-governments to a considerable degree. Many local self-governments led by the governing political parties passed such a resolution during the campaign expressing the attitude and the will of the municipality; meaning that settlement of immigrants was refused in their city or village. Such declarations ${ }^{36}$ were not isolated appearances of a policy's result, but rather the implementation of central guidelines. For example, the Alliance of Cities of County Status, one of the local governments' associations, namely the association of the major cities in Hungary, published a declaration that was released at their conference of 12 January $2018 .{ }^{37}$ This declaration was an appeal published by 23 cities toward other local governments to refuse the settlement of immigrants.

If the question is whether all Hungarian municipalities approve anti-immigrant local policies, a clear answer is very difficult to give. Many of them do, because the local policies of the majority of Hungarian municipalities are influenced centrally by the governing party through the elected council or mayor. Out of the 3163 Hungarian mayors 612 of them are members of the governing party. This would not seem like a lot, but they govern the most important municipalities. It is true however that the majority of the

35 http://www.europarl.europa.eu/sides/getDoc.do?pubRef=-//EP//TEXT+RE$\mathrm{PORT}+\mathrm{A} 8-2017-0345+0+\mathrm{DOC}+\mathrm{XML}+\mathrm{V0} / / \mathrm{EN}$

36 Only a few examples are: 15 December 2017 - Székesfehérvár, 25 January 2018 Debrecen, Kaposvár, Szolnok, Szekszárd and Nógrád County.

37 The title of this conference was „Mayors' cooperation against the agencies organising immigration". 
mayors (2447) are independent, meaning they are not members of any political party, but independent mayors who were elected in small villages where personal relationship outweighs partisanship. Consequently, there are only 104 communes, including some cities, where the mayor belongs to one of the parties of the government's opposition. Of more importance however is the composition of the local council (body of representatives) that exercises the decision-making power. It is not possible to present all the results of the municipal elections of 2014 in this paper, but the results in the major cities tell a lot: in 20 of the 23 major Hungarian cities, city councils are dominated by the governing party and the political situation is the same in the capital city. ${ }^{38}$ Another considerable fact is that there are no more masses of migrants in Hungary, consequently a different local policy, if there would be one, is not apparent, and as some cases show it is not rewarding for local politicians either. So, if there is any disagreement between different political parties or actors, it is not broadly published.

\section{Conclusion}

Our conclusion is that it is almost impossible to talk about local self-governments in Hungary as having their own policy on migration. Formally, it is visible that the policy on migration is exclusively formulated, or at least strongly influenced, by the central government and is implemented under strong control by its local agencies. Since the migration issue is controlled by the state in this way, local self-governments have nothing left to do in dealing with migration in practice. In a legal sense, they may have local initiatives, which they have volunteered to undertake as public duties. But several examples show that public opinion, strongly influenced by the government controlled policy, does not favour local initiatives aimed at supporting migrants or their integration. Consequently, most of the municipalities do not undertake the initiatives that they are however entitled to due to lack of public support. In Hungary, local self-governments' participation in the integration of migrants can be qualified as considerably weak. Hungarian municipalities therefore do not take measures of their own for the integration of migrants, instead they have a "policy concerning integration," which is hardly influenced by the central government.

38 The data has been retrieved from the official site of the National Election Office: http://www.valasztas.hu/dyn/onk14/szavossz/hu/topmand.html 


\section{References}

Nagy, B. (2018). From reluctance to total denial: Asylum policy in Hungary 2015-2018. In V. Stoyanova, \& E. Karageorgiou (eds.) The new asylum and transit countries in Europe during and in the aftermath of the 2015/16 crisis (pp. 17-65). Leiden, the Netherlands/Boston, USA: Brill Nijhoff. DOI 10.1163/9789004368293_003

Temesi, I. (2018). Administrative background and the process of migrant integration in Hungary. Croatian and Comparative Public Administration, 18(3), 421-446. DOI 10.31297/hkju.18.3.2

Temesi, I. (2017). The swinging pendulum of decentralization in Hungary. In J. M. Ruano \& M. Profiroiu (ed.), The Palgrave handbook of decentralisation in Europe (pp. 417-441). Cham, Switzerland: Palgrave Macmillan. DOI 10.1007/978-3319-32437-1_16

\section{Legal sources and documents}

The Fundamental Law of Hungary,retrived from https://www.kormany.hu/download/f/3e/61000/TheFundamentalLawofHungary_20180629_FIN.pdf

Legislative Act No. XC of 2017 on Criminal Procedure

Legislative Act No. CLXXXIX of 2011 on Local Self-Governments

Legislative Act No. C of 2012 on the Penal Code

Legislative Act No. LXXX of 2007 on Asylum

Legislative Act No. XLI of 2018 on the Modification of Certain Legislative Acts on Taxation and Related Legislative Acts as well as on the Immigration Super-tax

Government Decree No. 301 of 9 November 2007 on the Execution of the Legislative Act on Asylum

Local Decree No. 25 of 23 November 2016 of the Commune of Ásotthalom,

Local Decree No. 18 of 23 November 2017 of the Commune of Ásotthalom.

Local Decree No. 8 of 4 July 2016 of the Commune of Esztergályhorváti

Resolution of the Parliament No. 29/2017 of 13 December 2017 on the European

Parliament's Resolution on the Implementation of the Soros-Plan

Resolution of the Government No. 1724/2015 of 7 October

\section{LOCAL SELF-GOVERNMENTS IN DEALING WITH MASS MIGRATIONS AND INTEGRATION OF MIGRANTS IN HUNGARY}

\section{Summary}

In Hungary migration is an issue almost exclusively and entirely managed by the central government through its agencies. The policy on migration and its 
implementation are decisively handled by the government. The legal background is arranged through legislation that serves political purposes: a coherent system of new legislative acts and decrees were passed, and others were modified. The implementation of this disposition is realized by authorities directly controlled by the government, including the decisions made on requests for asylum, other types of recognition, or for subsidies. In this centralized system, not much is left to do for local self-governments. Legislation deprived local self-governments of the possible instruments that would serve the management of migration. The decision makers of local self-governments are strongly influenced by the central political guidelines, as well as by the local population. Thus, the issue of supporting the integration of migrants by Hungarian local self-governments is very difficult to examine.

Keywords: immigration authority, integration of migrants, local policy, local self-government, mass migration, refugees

\section{ULOGA MAĐARSKE LOKALNE SAMOUPRAVE U RJEŠAVANJU PROBLEMA MASOVNIH MIGRACIJA I INTEGRACIJE MIGRANATA}

\section{Sažetak}

Pitanje migracije u Mađarskoj gotovo je isključivo i u cijelosti u nadležnosti središnje države $i$ njezinib tijela, a migracijska politika i njezina provedba pod strogim su nadzorom vlade. Doneseno je zakonodavstvo koje služi svrhama koje je odredila politika. Radi toga je donesen niz uskladenib zakona i uredbi, dok su neki od ranije postojećib propisa promijenjeni da bi se prilagodili tako ustanovljenim svrhama. Njihova provedba je u rukama tijela koja neposredno nadzire vlada, što se posebno odnosi na odluke o zabtjevima za azil te o drugim pravima i pomoćima. U tako centraliziranom sustavu malo je mjesta za lokalnu samoupravu. Zakonodavstvo je lokalnoj samoupravi uskratilo moguće instrumente kojima bi utjecala na upravljanje migracijama. Donositelji odluka na lokalnoj razini pod jakim su utjecajem kako središnje vlasti tako i lokalnog stanovništva. Zbog toga je vrlo izazovno istraživati ulogu mađarske lokalne samouprave u integraciji migranata.

Ključne riječi: imigracijske vlasti, integracija migranata, lokalne javne politike, lokalna samouprava, masovne migracije, izbjeglice 